\title{
How to Narrow Agriculture Formal and Empirical Knowledge Gap in Rural Settings of Developing Countries?
}

\author{
Ramirez Restrepo Andres* \\ University of Antioquia, USA
}

Submission: April 27, 2018; Published: May 14, 2018

*Corresponding author: Ramirez Restrepo Andres, University of Antioquia, Columbia, USA, Tel: +574 2196571; Email: quimico.andres@gmail.com

\begin{abstract}
Agriculture is a main activity in the primary sector of the economy. In developing countries, the labor force of agriculture consist of people with nonexistent, primary or secondary educational level, and most of them rely in empirical practices, so a gap between formal and empirical knowledge seems to exist. A further analysis explores contributions of both in the context of agriculture and rural settings, aiming to find a inclusive viewpoint of these knowledges seeing them as a complement for each other. Learning environments in accordance with the context could narrow the knowledge gap, but further discussion is needed.
\end{abstract}

Keywords: Knowledge gap; Rural setting; Developing country

\section{Introduction}

The primary sector of the economy can be considered the most important of all: other sectors of the economy, and even living in general, would not be possible without the availability of natural resources including those obtained through agriculture.

In developing countries, the largest share of GDP is due to activities such as agriculture, hunting, forestry and fishing. The labor force working in these activities has a formal education that can range from nonexistent to secondary education; and most of them start working at a young age simultaneously while they study. There seems to exist an incompatibility between study and work in this scenario, as people see them inconvenient to each other. The formal knowledge, obtained by studying, and the empirical knowledge obtained by working are also seen as useless to each other and even contradictory; a misconception quite far from reality [1]. Because of the situations described above, primary and secondary rural students tend to choose one of both possibilities, formal or empirical knowledge, disregarding the possibility that both may be necessary to improve their nearest environment, the rural sector and its economic activities. Is it possible to narrow the gap between formal and empirical knowledge in the rural settings of developing countries?

\section{Contribution of formal knowledge}

Those devoted to work and concrete actions may consider that school is a waste of time as the values and skills needed to labour in the field are not taught there, but by personal experience. However, and even unknowingly, those are the same people who apply basic concepts of science in common activities in agriculture such as preparing the right dosage of a pesticide (concentration), cultivation in greenhouses that regulate the temperature and moisture (thermodynamics) and rodent control by the introduction of predators (food chains).

A contribution comes as a possibility to standardize the process [2]. As an example, for the non-technified production of flowers and foliages, moon phases are used as a guide to choose times to sow, fertilize or apply other products and harvest. There is a scientific rationale behind this practice [3], but this knowledge is not known, understood or widespread among workers, leading to unstandardized practices. Because of that, the results are attributed to the called "good hand" (buena mano), a combination of talent and experience that determines if a person is able to work in the field. While those factors may, indeed, have influence in the results of the process, they should not be main and only ones to describe the performance of a worker. Other controllable and significant factors may be at play, and taking them into account could have positive impacts such as improve or stabilize the process, decrease efforts and manual labor and allow a wide number of people to participate and develop necessary skills to work. 
The formal knowledge needed for standardization may also include the basics of process control, management of documents and records, quality control and such, as it can prove to be difficult to control a process if the scientific concepts are known but control practices are not. This needs the basic formal knowledge to read, interpret and implement a written text but even nowadays in developing countries there is a illiteracy rate, higher in rural and remote settings, that needs to be overcome.

Another contribution is the improvement of value. If the labor force knew the scientific foundations of the common practices in agriculture, they could use them to their advantage and improve the process in many different ways such as production with increased output, better quality (size, color, flavour) of the harvest or healthier products, either because they have suffered less diseases in the cultivation process or because a reduced exposure to pesticides and fertilizers.

Finally, the formal knowledge allows an accurate decision making. Agriculture as an economic activity has a high variability, explained by changes in weather, seasons, and in living things. When unexpected changes happens, a decision must be made in order to preserve the plants or animals affected. As an example, pesticides are used to maintain grass free of pests in order to feed livestock and dairy cattles. If pests arrive often then the common sense solution would be to apply higher doses and/ or higher frequencies of the pesticides. The initial problem may be solved, but another one has been crafted, as the milk and meat may have higher concentration of such pesticides in unacceptable amounts. This cannot be known at first glance, and needs a solution that balances both factors, which may only be obtained through research and development; both forms of formal knowledge [4].

\section{Contribution of empirical knowledge}

It is important to recognize the value of the experience of those who have dedicated their lives to agriculture, even if their knowledge is purely empirical. Floriculture in Antioquia, Colombia, is an example of empirical knowledge transmitted via familiar tradition through generations. This is valued at such degree that flower cultivation is considered in some municipalities an art and there is a national parade in the honor of this heritage. Accordingly with this, the empirical knowledge translates in a sense of belonging; as it is tied with personal, familial and cultural experiences; that moderates the migration from the countryside to the cities, and from the rural work to less effort more profitable jobs. This migration can become a vicious circle, as less people in agriculture for the same output needed requires more sophisticated practices and technification, thus the formal knowledge needed is higher and more opportunities outside the rural settings become available and more people migrates. While technification comes as a consequence of this urbanization phenomena, the overall development of the sector is doubtly positive $[5,6]$.
Empirical knowledge also contributes specific information that may not be found elsewhere. Professionals may have a deep knowledge about related topics, but it may not be comprehensive, specific or contextualized enough to be applicable. For example, differences between the reported soil nutrients needed in literature and what field experience tells: while the formal principles remain, an adaptation process to the specific conditions is needed. Adaptations may follow several paths from trial and error to meticulous experiment designs, and it is often seen, due the variability of agricultural activities, that experience provides a valuable baseline and drives the rationale of such adaptation processes [7].

\section{Conclusion}

Both formal and empirical knowledge contribute in significant and complementary ways to agriculture and rural development. Formal knowledge provides enough background to properly standardize, improve value and allow accurate decision making, while empirical knowledge ties people, gives context and specific information only obtainable via experience. The gap between formal and empirical knowledge then, may be narrowed by systematically creating learning environments that demonstrate and promote the contextualized use of both types of knowledge. Being that educational level is, at most, in secondary studies, a further discussion may open as the rural schools could play a key role in this process of narrowing knowledge gaps.

\section{Acknowledgement}

The author acknowledges the Agriculture Engineer Olga Lucia Restrepo Mesa, for her valuable contribution of expertise and examples related to this opinion.

\section{References}

1. Tambo JA, Wünscher T (2018) Building farmers' capacity for innovation generation: Insights from rural Ghana. Renewable Agriculture and Food Systems 33(2): 116-130.

2. Pengfei He, Jing Li, Xin Wang (2018) Wheat harvest schedule model for agricultural machinery cooperatives considering fragmental farmlands. Computers and Electronics in Agriculture 145: 226-234.

3. Zajączkowska U, Barlow PW (2017) The effect of lunisolar tidal acceleration on stem elongation growth, nutations and leaf movements in peppermint (Mentha $\times$ piperita L.). Plant Biol (Stuttg) 19(4): 630642.

4. Peñuela Mesa, Gustavo Antonio, Gallo Ortiz, Andrés Fernando, Hoyos Ossa, et al. (2013) Chapter 7 - GC-MS Applied to the Monitoring of Pesticides in Milk an Blackberries and PAHs in Processed Meats of Colombia. In: Achille Cappiello, Pierangela Palma, (Eds.), Comprehensive Analytical Chemistry. Elsevier, USA, 79: 159-180.

5. Yan Teresa (2012) Harvard Political Review. From Countryside to City, United States of America.

6. Essays UK (2013). Migration From The Countryside To Cities Environmental Sciences Essay. England.

7. Mendoza JR, Sabillon L, Martinez W, Campabada C, Hallen-Adams HE, et al. (2017) Traditional maize post-harvest management practices amongst smallholder farmers in Guatemala. Journal of Stored Products Research 71: 14-21. 
This work is licensed under Creative Commons Attribution 4.0 License

DOI: 10.19080/ARTOAJ.2018.16.555976
Your next submission with Juniper Publishers will reach you the below assets

- Quality Editorial service

- Swift Peer Review

- Reprints availability

- E-prints Service

- Manuscript Podcast for convenient understanding

- Global attainment for your research

- Manuscript accessibility in different formats

( Pdf, E-pub, Full Text, Audio)

- Unceasing customer service

Track the below URL for one-step submission https://juniperpublishers.com/online-submission.php 